\title{
Hotel and Restaurant Tax Domination as a Source of Local Revenue of Badung Regency: A Study Amidst the Covid-19 Pandemic Era
}

\author{
Made Satria Pramanda Putra \\ Program Studi Teknologi Informasi, Institut Teknologi dan Bisnis STIKOM Bali, Bali-Indonesia \\ satria_pramanda@stikom-bali.ac.id
}

Published: 30/09/2020

How to cite (in APA style):

Putra, Made Satria Pramanda. (2020). Hotel and Restaurant Tax Domination as a Source of Local Revenue of Badung Regency: A Study Amidst the Covid-19 Pandemic Era. Jurnal Ekonomi dan Bisnis Jagaditha, 7(2), 114-122. doi: https://doi.org/10.22225/jj.7.2.2375.42-50

\begin{abstract}
Pandemic Covid-19 has put significant pressure on the tourism sector and has an impact on the realisation of hotel and restaurant tax revenues in Badung Regency. This condition requires strategic steps from the Badung Regency Government to realize optimal tax revenue. The aims of this study is to examine the steps taken by the Badung Regency Government to optimise the regional tax collection from Hotel and Restaurant Taxes. This paper provides a qualitative study. Research informants are all officials in the Badung Regional Revenue Agency (Bapenda Badung Regency) as the Regional Apparatus Organization (OPD) in charge of carrying out hotel and restaurant tax levies. Data collection techniques are observation, interview and documentation study. Data collection through interview is carried out in depth and when in saturated condition will end. This study obtained results that the strategic steps taken by the Badung Regency Government in an effort to optimize the reception of Hotel and Restaurant Taxes, include (1) Utilization of Information Technology, (2) Dissemination and Education, (3) Issuance of Regulations, (4) Tax Extensification, (5) Tax Intensification, (6) Monitoring and Evaluation and (7) Legal Supremacy.
\end{abstract}

Keywords: Covid-19 Pandemic; Hotel Tax; Local/Regional Tax; Restaurant Tax

\section{INTRODUCTION}

Tax serves as a source of income for a state. Law Number 6 of 1983, the last of which was amended to Law Number 16 of 2009 concerning General Provisions and Tax Procedures, defines the tax as "compulsory contribution that is compelling owed by an individual or entity to the state based on Law, with no direct compensation and is used for the state's needs for the greatest prosperity of the people". Such a definition is in line with the views of (Mardiasmo, 2019; Soemitro, 2014; Waluyo, 2017). Taxes take the form of people's contributions to the state, the imposition of which can executed based on regulations without direct reciprocity and is used to finance general expenses.

In terms of collection agency, taxes can be classified into central tax and local/regional tax. For the regional tax, the administration of collection is carried out by each autonomous region for the affairs of financing regional household expenses. With regard to the regional tax, (Adisasmita, 2011; Siahaan, 2016) argue that local taxes refer the obligation of the community to surrender part of their the wealth to the regions which are then used to finance the government administration and regional development. Regional tax serves as an crucial source of regional income used for funding the regional government administration with regard to the principle of justice by taking into account the potential of each region.

As an autonomous region, the Badung Regency Government has collected Regional Taxes. The types of the Regional Taxes collected 
by the Badung Regency Government include (1) Hotel Tax, (2) Restaurant Tax, (3) Entertainment Tax, (4) Parking Tax, (5) Ground Water Tax, (6) Advertisement Tax, ( 7) Tax on Non-Metallic Mineral and Rock, (8) Tax on Rural and Urban Land and Building, (9) Tax on Land and Building Rights Acquisition and (10) Tax on
Street Lighting. Of the 10 (ten) types of tax collected, in the last 5 (five) years the realisation of Regional Tax revenue in Badung Regency was dominated by 2 (two) types of taxes, such as: Hotel Tax and Restaurant Tax as shown in the following figure.

Figure 1. Realisation of Revenue from Hotel Tax, Restaurant Tax and Other Local Taxes of Badung Regency

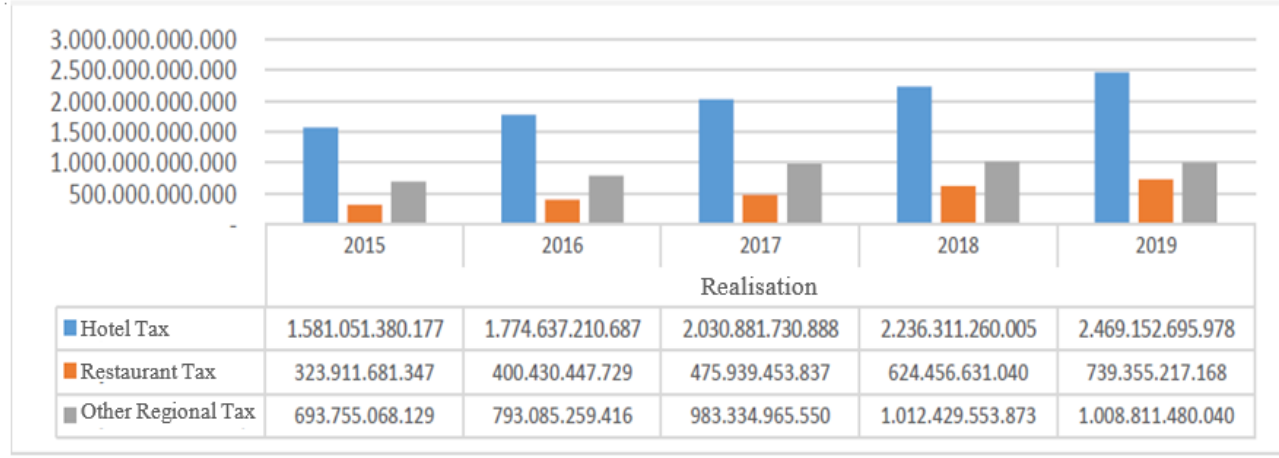

Source: Processed from Tax Revenue Realisation Data, Bapenda Badung Regency

Figure 1.0 indicates that the proportion of the Hotel and Restaurant Tax component during the last 5 (five) years has made contributions significantly compared to other types of taxes. The average contribution of Hotel and Restaurant Tax during the 2014-2019 period was $73.67 \%$. The highest percentage occurred in 2019 , in which, $76.68 \%$ of all types of the regional tax revenue from the Badung Regency Government came from hotel and restaurant taxes. The high proportion of revenue from Hotel and Restaurant Tax is due to the growth experienced by the tourism sector as the main driver of economic activity in Badung Regency. Data on Gross Regional Domestic Product (GRDP) of Badung Regency indicate that the regency's economic structure is dominated by 2 (two) categories, namely: Provision of Accommodation-Food and Drinks and Transportation-Warehouse. Since 2014-2018, the two categories have an average contribution of $28.85 \%$ and $24.88 \%$.

Since the first quarter of 2020, the Covid-19 pandemic has put significant pressure on various sectors of the economy. The tourism industry has become one of the sectors that is experiencing the strong pressure. This can be shown through data on the number of foreign tourists in May 2019 compared to that of May 2020. The number of foreign tourists to Bali recordedly decreased by almost 100 percent (-99.99\%). Furthermore, the Room Occupancy Rate (TPK) of star-rated hotels, using the comparison in the same period, also recordedly decreased by 49.49 points (Badan Pusat Statistik Provinsi Bali, 2020).

The size of the amount of the regional tax revenue from the Badung Regency Government is excessively dependent on the objective conditions of tourism industry. The strength of pressure due to the Covid-19 Pandemic is shown through the data on the achievement of the realisation of regional tax revenues in Badung Regency in the current year of 2020, as shown in Table 1.0. 
Table 1. The Regional Tax Revenue Realisation in Badung Regency in 2020

\begin{tabular}{|c|c|c|c|}
\hline \multirow[b]{2}{*}{ Type of Tax } & \multicolumn{3}{|c|}{$2020 *$} \\
\hline & Target & Realisation & Accomplishment \\
\hline Hotel & 2.700 .053 .883 .601 & 613.852 .053 .227 & $22,73 \%$ \\
\hline Restaurant & 840.858 .085 .471 & 175.449 .472 .067 & $20,87 \%$ \\
\hline Entertainment & 125.944 .223 .924 & 28.032 .779 .964 & $22,26 \%$ \\
\hline Parking place & 32.638 .469 .429 & 9.221 .362 .617 & $28,25 \%$ \\
\hline Ground water & 77.999.755.545 & 25.842 .850 .035 & $33,13 \%$ \\
\hline Advertisement & 5.000 .000 .000 & 355.478 .733 & $7,11 \%$ \\
\hline $\begin{array}{l}M B L B \text { (Non- } \\
\text { Metallic Minerals } \\
\text { and Rocks) }\end{array}$ & 146.542 .442 & 8.737 .500 & $5,96 \%$ \\
\hline $\begin{array}{l}P B B P-2 \text { (Rural } \\
\text { and Urban Land } \\
\text { and Building Tax) }\end{array}$ & 228.193 .704 .024 & 6.899 .540 .061 & $3,02 \%$ \\
\hline $\begin{array}{l}\text { BPHTB (Land and } \\
\text { Building Title } \\
\text { Acquisition Fee) }\end{array}$ & 600.000 .000 .000 & 81.686 .707 .419 & $13,61 \%$ \\
\hline $\begin{array}{l}P P J(\text { Street } \\
\text { Lighting Tax })\end{array}$ & 150.000 .000 .000 & 65.937 .686 .147 & $43,96 \%$ \\
\hline Total & 4.760.834.664.436 & 1.007 .286 .667 .770 & $21,16 \%$ \\
\hline
\end{tabular}

Source: Processed from Tax Revenue Realisation Data, Bapenda Badung Regency (*data in June 2020)

Data up to June 2020 shows the lowest percentage of realisation came from the Rural and Urban Land and Building Tax (PBB P-2), that is, $3.02 \%$. Furthermore, the highest percentage of accomplishment was the realisation of Street Lighting Tax (PPJ) revenue of $43.96 \%$. Even with the highest realisation, when viewed from its contribution to the target, the PPJ only contributed $3.15 \%$ of the total Regional Tax target. On the other hand, the accomplishment of Hotel and Restaurant Tax until June 2020, which in composition contributed $74.38 \%$ of the Regional Tax target, was only $22.29 \%$.

The pressure put by the Covid-19 Pandemic on the tourism sector certainly has a significant impact on regional financial conditions. The emergence of the Covid-19 Pandemic amidst the dependence of regional revenues on the realisation of Regional Tax revenues originating from Hotel and Restaurant Taxes appears as an important discussion, especially regarding what strategic steps the Badung Regency Government should take in anticipating a decrease in Hotel and Restaurant Tax revenue. Established on this description, the problem examined in this study is the steps taken by the Badung Regency Government to optimise the regional tax collection from Hotel and Restaurant Taxes.

\section{CONCEPTUAL FRAMEWORK}

\section{a. Locally-generated revenue}

Locally-generated Revenue $(P A D)$ serves as a source of regional income other in addition to the transfer income and other legitimate regional revenues. Law Number 33 of 2004 concerning Financial Balance between Central and Regional Government defines the $P A D$ as "revenue obtained by regions which is collected based on Regional Regulations in accordance with statutory regulations". The definition is in line with (Halim, 2004) view defining the $P A D$ as "revenue obtained by a region from sources within its own territory which is collected based on regional regulations in accordance with applicable laws and regulations". Based on Law Number 23 of 2014 concerning Regional Government, PAD includes: (1) local taxes; (2) regional retribution; (3) proceeds from the management of separated regional assets; and (4) other legitimate locally generated revenues.

\section{b. Local Tax}


Adisasmita, (2011); Siahaan, (2016) argue that local tax encompasses the obligation of the community to surrender part of the their wealth to the regions which are used to finance local government administration and regional development. Regional tax serves as one of the sources of regional income which has an important role in the interest of funding the regional government administration based on the principle of justice by taking into account the regional potentials.

The regulation governing the Regional Taxes is the Law Number 28 of 2009 concerning Regional Taxes and Regional Levies ( $U U$ PDRD). Based on Article 2 paragraph (2) of the $U U P D R D$, the types of district/city taxes consist of: (1) Hotel Tax; (2) Restaurant Tax; (3) Entertainment Tax; (4) Advertisement Tax; (5) Street Lighting Tax; (6) Non-Metal Mineral and Rock Tax; (7) Parking Tax; (8) Groundwater Tax; (9) Tax on Swallow's Nests; (10) Rural and Urban Land and Building Tax; and (11) Land and Building Title Acquisition Fee.

\section{c. Hotel Tax}

The UU PDRD defines hotel as an accommodation/resort service provider including other related services with payments, which also include motels, guesthouses, tourist huts, tourism guesthouses, lodging houses and the like and boarding houses with more than 10 (ten) rooms. The objects of hotel tax are services provided by hotels with payment, including supporting services as hotel amenities which provide convenience and comfort, including sports and entertainment facilities.

\section{d. Restaurant Tax}

The UU PDRD defines a restaurant as a facility for providing food and/or drinks with payments, which also includes restaurants, cafeterias, canteens, stalls, bars, and the like, including catering services. Furthermore, the object of restaurant tax is the service provided by the restaurant which includes services for the sale of food and/or drinks consumed by the purchaser, whether consumed at the service place or at other places.

\section{e. Strategy}

Strategy can be defined as an action carried out in a sustainable manner by adjusting the strengths and weaknesses of an organisation. Argyris, (1985); Siagian, (2004) describe the strategy as a series of decisions and actions to adapt to various disturbances, both from inside and outside the organisation. Strategies are made by top management and implemented by all levels of an organisation in order to achieve its organisational goals.

\section{METHOD}

This study employs a qualitative descriptive approach, in that, it is made to describe the results of the study by comparing the occurring phenomena with the theory. This study makes use of primary data sources and secondary data sources. Primary data are collected from informants and the secondary ones are collected from related agencies and literature. In terms of research approach, there are two types of data needed, quantitative data and qualitative data. The required quantitative data are in the form of numbers such as the realisation of local tax revenue. Meanwhile, the required qualitative data are in form of results of interviews with informants. Interviews conducted with informants were conducted using a snow ball model, in that, if the process was deemed saturated, the interview would end. The data collection techniques other than interviews are observation and documentation study and to the testing of the data validity was done through triangulation technique with a source approach.

\section{RESULTS AND DISCUSSION}

Regulation governing the Regional Tax is the Law Number 28 concerning Regional Taxes and Regional Levies ( $U U$ PDRD). Referring to Article 2 paragraph (2) of the $U U$ PDRD, the types of Regional Taxes at the Regency level comprise: (1) Hotel Tax, (2) Restaurant Tax, (3) Entertainment Tax, (4) Advertisement Tax, (5) Street Lighting Tax, (6) Tax on Non-Metallic Mineral and Rock, (7) Parking Tax, (8) Groundwater Tax, (9) Swallow's Nest Tax, (10) 
Rural and Urban Land and Building Tax ( $P B B$ $P-2)$ and (11) ) Land and Building title Acquisition Fee (BPHTB).

Apart from the types mentioned in the $U U$ $P D R D$, Regional Governments are prohibited from collecting taxes and even the collection shall be adjusted to the policies and potential of each autonomous region. Furthermore, based on
Law Number 23 of 2014 concerning Regional Government, PAD includes: (1) Regional Taxes, (2) Regional Levies, (3) Proceeds from the Management of Separated Regional Assets; and (4) Other legitimate $P A D$. The realisation of local tax revenue from the Badung Regency Government for the last 5 (five) years is presented in Figure 2.0.

Figure 2. Achievement of Badung Regional Tax Revenue in 2015-2019

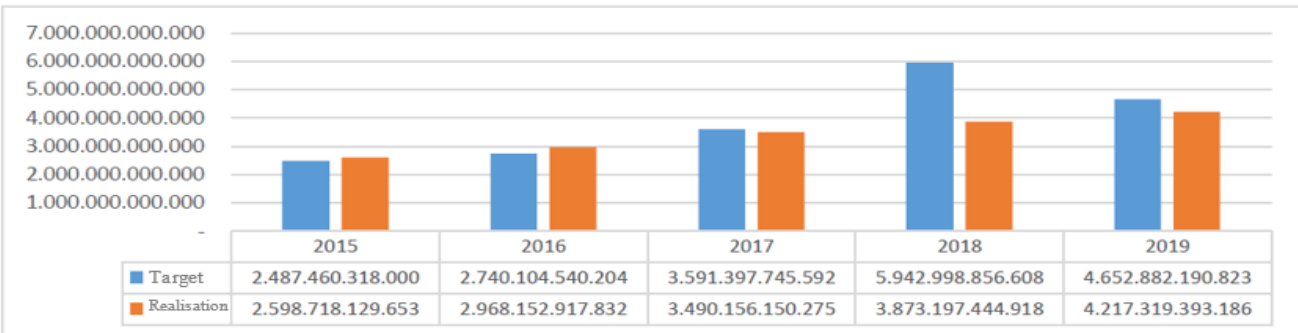

Source: Processed from Tax Revenue Realisation Data, Bapenda Badung Regency

Based on Figure 2.0, during the last 5 (five) years, the highest regional tax revenue achievement occurred in 2016, which was $108.32 \%$. Furthermore, since 2017 the realisation of Badung Regional Tax revenue has not reached the predetermined target. In 2017, the realisation of the Regional Taxes was $97.18 \%$. The lowest achievement came to pass in 2018 at $65.17 \%$. The series of natural events in the eruption of Gunung Agung beginning at the end of 2017 to 2018, which resulted in the temporal cessation of transportation activities especially air transportation through Gusti Ngurah Rai International Airport I - certainly had an impact on various sectors of the economy, including the tourism sector which has become the main support for the regional tax revenue of the Badung Regency. In line with the stability of Gunung Agung's activities and return to normal transportation activities, in 2019 the achievement of Regional Tax revenues has increased to $90.64 \%$.

Although it has been currently under pressure due to the Covid-19 Pandemic, various modes of avoidance in the Regional Tax collection process still have the potential to occur and will potentially cause leakages in the Regional Tax revenues. Given the situation and condition of the Covid-19 Pandemic having taken place, extra efforts are necessary which at the same time accompanied by strategic steps to optimise the local tax revenue. Grounded with these facts, a strategy to solve the problem in question is needed in order that that the tax collection during the pandemic can be executed out optimally. The success in collecting the taxes amidst the pandemic situation is largely determined by a strategy. As expressed by Argyris, (1985); Siagian, (2004), there is a need for a strategy to achieve a goal. Therefore, the strategic steps having been taken by the Badung Regency Government to optimise the Hotel and Restaurant Tax are as follows.

\section{a. Information Technology Utilisation}

In dealing with the Covid-19 Pandemic, a face-to-face service needs to be implemented to a minimum to reduce the spread of the virus. Therefore, utilisation of information technology as a tool is one of the strategic steps that have been taken by the Badung Regency Government. Information technology application is realised through the application of online Hotel and Restaurant Tax reporting. In addition to the application of information technology related to reporting administration, the Badung Regency 
Government has also collaborated with several related banks to facilitate taxpayers in making tax payments, one of which is Bank BPD Bali. At Bank BPD Bali, tax payments can be made via ATM, M-Banking, Internet Banking and Virtual Accounts. Bill payments are made faster, easier and safer considering that for one transaction, taxpayers will get a Virtual Account Number. Apart from Bank BPD Bali, the Badung Regency Government has also collaborated with Bank Mandiri. The various payment channels having been provided are expected to facilitate the taxpayers in making the tax payments.

The existence of reliable information technology has a vital role in tax collection administration. This is because information technology is closely related to service quality. Through the use of information technology, the services provided are becoming faster, more precise and accurate. This is in line with the standpoint of (Zeithaml, Parasuraman, \& Berry, 1990) claiming that responsiveness is one of the dimensions of service quality. The quality of a service is exceedingly determined by the nature of fastness, responsiveness and instantenoussness in the service delivery process.

Quality services to taxpayers are expected to be able to optimise the local tax revenue. Abidin, (2010) argues that "the aspects of fastness, accuracy, ease, and indiscrimination serve as a tool to measure a quality public service". The utilisation of information performs as a tool to accelerate, simplify and facilitate the service process for taxpayers. A faster, more precise and accurate service is the key to success for an organisation, including the Badung Regency Government in optimising the local tax revenue.

\section{b. Socialisation and Education}

Tax socialisation is carried out with various purposes, which include conveying information on tax regulations, tax obligation-related technical guidance, as well as education for the purpose of increasing taxpayer awareness. Socialisation activities can be held at various places, times and with various socialisation media.

The Badung Regency Government has continued to conduct the outreach to taxpayers, especially socialisation related to current issues in the field of taxation. The delivery of information to taxpayers is carried out through various media. Amid the Covid-19 Pandemic situation, the delivery of information to taxpayers focuses more on an execution via electronic mail (email). In addition, various types of information are also conveyed by the Badung Regency Government through the official website of Bapenda Kabupaten Badung on the web page: https://badungkab.go.id/instansi/bapenda/home and through a social media account @bapendabadung.

Misbach in (Utomo, 2011) reveals that the success of tax revenue represents the reflection of public awareness. Hence, the implementation of socialisation is expected to be able to raise the taxpayer awareness, considering that the taxpayer awareness has a very strong influence on the realisation of tax revenue. Taxpayers who voluntarily make their tax obligation payment are the ones who are aware of the essence of the tax itself. The higher the level of taxpayer awareness, the higher the realisation of state revenue originating from the taxation sector. This view is in line with the results of (Safri, 2013) research revealing that one of the obstacles in achieving tax revenue realisation is the taxpayer awareness factor. Secondly, the view is also supported by the view of (Imaroh, 2016) arguing that taxpayer awareness can be increased through the education sector and the dissemination of free information either through tax brochures, leaflets or bulletins.

\section{c. Issuance of Regulations}

The Covid-19 pandemic is a national disaster that affects the productivity of society and business actors in various sectors of economy. Established on the fact, efforts to regulate taxation stimuli have been made to support the economic stability. The tax function is not 
limited only as a source of state income. Apart from the budget function, tax can also function as a regulatory instrument. This is in line with the official view (2014) stating that taxes have two functions, namely: budgetair and regulerend.

The issuance of regulations providing tax stimuli is one of the efforts of the Badung Regency Government to minimise the impact of the Covid-19 Pandemic. The provision of stimulus to taxpayers is carried out by issuing the Regent Regulation Number 27 of 2020 concerning Reduction or Abolition of Regional Tax Administrative Sanctions in the Context of Handling the Economic Impact of Corona Virus Disease 2019. The issuance of this regulation aims at reducing the administrative sanctions for taxpayers with the aim of making repayment of the unpaid tax principal during the Covid-19 Pandemic.

\section{d. Tax Extensification}

Extensification in terms of taxation is an effort to optimise tax revenue by increasing the number of registered taxpayers. Christover \& Rondonuwu (2016) claim tax extensification as an activity to find tax subjects who have met the requirements as taxpayers but have not been registered as taxpayers. Furthermore, in the Circular Letter of the Director General of Taxes Number SE-06/PJ.9/2001, Taxpayer extensification is an activity related to increasing the number of registered taxpayers and expanding tax objects in the administration of the Directorate General of Taxes (DGT).

The Badung Regency Government has taken extensification steps through data collection and registration of new taxpayers. Tax extensification activities performed until June 2020 resulted in the addition of 228 hotel taxpayers. Meanwhile, for restaurant taxpayers, there is an additional of 125 taxpayers.

The increase in the number of new taxpayers is expected to be able to optimise the tax revenue. This is in line with the results of research of (Setiawan, 2007) at Kantor Pelayanan Pajak Palmerah finding taht the number of taxpayers has a linear effect on tax revenue. Thus, efforts to add new taxpayers that have been and are being carried out by the Badung Regency Government, especially for hotel and restaurant taxpayers, are expected to optimise the hotel and restaurant tax revenue.

\section{e. Tax Intensification}

Tax intensification emerges as a step to optimise the extraction of tax revenues on tax objects and subjects that have been identified or registered in the administration of the tax authorities. The activity of optimising the extraction of tax revenues on the identified or registered objects and tax subjects aims to reveal the untrue, complete and clear taxpayer reports because many taxpayers, who have been registered, have not made the tax payment in accordance with applicable rules and regulations.

The government of Badung Regency has pursued the tax intensification by conducting tax audit. The focus of the tax audit is the period or tax year before the emergence of the Covid-19 Pandemic, which is between the 2017 tax year and the 2019 tax year. Article 11 paragraph (4) Badung Regent Regulation Number 15 of 2011 concerning Hotel Taxes and Article 11 paragraph (4) Badung Regent Regulation Number 16 of 2011 concerning Restaurant Tax stipulates that tax audits are executed to determine the taxpayer compliance in calculating, depositing and reporting the tax payable. The audit is carried out on the Regional Tax Return (SPTPD) along with the supporting documents and information. Based on the results of the audit, if there is a tax that still has to be paid - due to the value of the tax owed is greater than the tax credit - then a Regional Tax Underpayment Assessment Letter (SKPDKB), which must be paid by the taxpayer within a predetermined time, is issued.

\section{f. Monitoring and Evaluation}

According to Tulenan, Sondakh, \& Pinatik (2017), taxpayer awareness represents "the condition in which taxpayers know, understand and implement taxation provisions correctly and voluntarily". In line with this view, (Susilawati 
\& Budiartha, 2013) reveal that given that the taxpayers do not receive direct counterachievement from their obligations, a willingness and sincerity of taxpayers to fulfill their obligations is required. Facts on the ground show that there are still taxpayers who are not aware of their tax obligations and are trying to avoid them. Therefore, regular and continuous monitoring and evaluation steps from the tax authorities are necessary to increase taxpayer awareness.

The real steps taken by the Badung Regency Government are monitoring and evaluation of the taxpayer's business activities. Through its tax authorities, the agency has continuously monitored the Hotel and Restaurant Taxpayers who have temporarily closed and the Taxpayers who have reported tax status with zero since the Covid-19 Pandemic. The results of monitoring at the beginning of the Covid-19 Pandemic up to May 2020 show that most taxpayers are still closed. However, monitoring is still carried out regularly. In June 2020, although the majority of Hotel and Restaurant Taxpayers are still not operating, from the results of monitoring several restaurant taxpayers have restarted their operational activities. This is indicated by the increase in revenue realisation in May 2020 compared to that of June 2020, which amounted to 600 million rupiah.

\section{g. Legal Supremacy}

One form of law enforcement in the taxation sector is to collect local tax receivables. Article 1 number 9 of Law Number 19 of 1997 as amended to Law Number 19 of 2000 concerning Tax Collection by Force Letter (UU PPSP) stipulates "Tax Collection is a series of actions with the purpose that the Tax Bearer will pay off the tax debt and tax collection fees by admonishing or warning, implementing Immediate and Simultaneous Collection, notifying a Warrant, proposing prevention, carrying out confiscation, carrying out hostagetaking, and selling goods that have been confiscated. "In short, tax collection is a series of actions taken in order that the tax bearers pay off their tax debt and tax collection costs.

The procedure for the Regional Tax Colecction in Badung Regency is regulated in Badung Regent Regulation Number 15 of 2018. Tax collection is carried out if the tax debt listed in the Tax Assessment Letter is unpaid up to the predetermined due date. The Badung Regency Government undertook tax collection efforts to raise the awareness and a deterrent effect as well as provide legal certainty to taxpayers. The first step taken was to provide guidance and control of tax receivables for taxpayers who have arrears. The actions taken were in the form of direct field visits, admonition and warning taxpayers to immediately make their tax payments against the arrears of the previous tax year. Based on the data collected, from the efforts that have been made up to June 2020, 50 billion Rupiah has been realised. Furthermore, if admonition and warnings are set aside, the stages are continued in accordance with the authority granted by the statutory regulations, such as confiscation, auction, and hostage taking. Of course, all actions taken are within the applicable legal procedures and corridors and take into account the sustainability of the taxpayer's business, especially amidst the current Covid-19 pandemic conditions.

\section{CONCLUSION}

Established on the results of the analysis described above, the Badung Regency Government has taken various strategic steps in an effort to optimise the hotel and restaurant tax revenue. The steps that have been implemented include: (1) utilisation of information technology, (2) socialisation and education, (3) issuance of regulations, (4) tax extensification, (5) tax intensification, (6) monitoring and evaluation and (7) legal supremacy.

\author{
REFERENCES \\ Abidin, Z. S. (2010). Kebijakan Publik. Jakarta: \\ Yayasan Pancur Siwah. \\ Adisasmita, R. (2011). Pembiayaan Pembangunan \\ Daerah. Yogyakarta: Graha Ilmu. \\ Argyris. (1985). Strategy Change and Defensive
}


Routines. Marshfiels MA: Pitman Pub.

Badan Pusat Statistik Provinsi Bali. (2020). Berita Resmi Statistik Perkembangan Pariwisata Provinsi Bali. Bali: BPS Provinsi Bali.

Christover, A., \& Rondonuwu. (2016). Pemahaman Ekstensifikasi Wajib Pajak dan Intensifikasi Pajak terhadap Persepsi Fiskus tentang Penerimaan Pajak. Jurnal EMBA, 4(1).

Halim, A. (2004). Akuntansi Keuangan Daerah. Yogyakarta: Unit Penerbit Percetakan Akademi Manajemen Perusahaan YKPN.

Imaroh, T. S. (2016). Strategi Meningkatkan Kesadaran Wajib Pajak dalam Mewujudkan Pembangunan Berkelanjutan (SDGs). Prosiding Seminar STIAMI, III(1).

Mardiasmo. (2019). Perpajakan Edisi 2019. Yogyakarta: Penerbit Andi.

Safri, R. D. (2013). Pengaruh Kesadaran Wajib Pajak terhadap Kepatuhan Wajib Pajak Orang Prang Pribadi yang Melakukan Pekerjaan Bebas (Studi di Wilayah KPP Pratma Yogyakarta) (Universitas Negeri Yogyakarta).

Setiawan, D. A. (2007). Analisis Hubungan antara Ekstensifikasi Wajib Pajak dan Surat Setoran Pajakdengan Penerimaan Pajak (studi Kasus pada Kantor Pelayanan Pajak Jakarta Palmerah). Media Riset Akuntansi, Auditing, Dan Informasi, 7(1).

Siagian, S. P. (2004). Manajemen Strategi. Jakarta: Bumi Aksara.

Siahaan, M. P. (2016). Pajak Daerah dan Retribusi Daerah (Edisi Revisi). Jakarta: Rajawali Pers.

Soemitro, R. (2014). Asas dan Dasar Perpajakan Edisi Revisi. Bandung: Refika Aditama.

Susilawati, K. E., \& Budiartha, K. (2013). Pengaruh Kesadaran Wajib Pajak, Pengetahuan Pajak, Sanksi Perpajakan dan Akuntabilitas Pelayanan Publik Pada Kepatuhan Wajib Pajak Kendaraan Bermotor. E-Jurnal Akuntansi, 4(2).

Tulenan, R. A., Sondakh, J. J., \& Pinatik, S. (2017). Pengaruh Kesadaran Wajib Pajak, Kualitas Pelayanan Fiskus dan Sanksi Pajak terhadap Kepatuhan Wajib Pajak Orang Pribadi di KPP Pratama Bitung. Going Concern: Jurnal Riset Akuntansi, 12(2).

Utomo, B. A. W. (2011). Pengaruh Sikap, Kesadaran Wajib Pajak dan Pengetahuan Perpajakan terhadap Kepatuhan Wajib Pajak dalam Membayar Pajak Bumi dan Bangunan di Kecamatan Pamulang Kota Tangerang
Selatan (Universitas Islam Negeri Syarif Hidayatullah).

Waluyo. (2017). Perpajakan Indonesia Edisi 12 Buku 1. Jakarta: Salemba Empat.

Zeithaml, V. A., Parasuraman, A., \& Berry, L. L. (1990). Delivering Quality Service: Balancing Customer Perception and Expectation. New York: The Free Press. 